\title{
The impact of artisanal gold mining, ore processing and mineralization on water quality in Marmato, Colombia
}

\author{
Keith W. Torrance (D) Stewart D. Redwood - Alessandro Cecchi
}

Received: 23 June 2020/ Accepted: 18 March 2021/Published online: 11 April 2021

(C) The Author(s) 2021

\begin{abstract}
Marmato, Colombia, has been an important centre of gold mining since before the first Spanish colonizers arrived in 1536. The Marmato deposit is hosted in a dacite and andesite porphyry stock as sheeted sulphide-rich veinlet systems. The district is currently experiencing a surge in both major mining projects and artisanal mining, driven by sustained high gold prices. Ore from small-scale and artisanal gold mining is processed in numerous small mills (entables) around Marmato, which impact surface water quality through the discharge of milled waste rock slurry, highly alkaline cyanide-treated effluent, and high dissolved metal loads. To investigate the impact of artisanal mining and ore processing, water samples were collected in January 2012 from streams around Marmato. The average dissolved metal concentrations in impacted streams were $\mathrm{Zn}$, $78 \mathrm{mg} \mathrm{L}^{-1}$; $\mathrm{Pb}, 0.43 \mathrm{mg} \mathrm{L}{ }^{-1}$; $\mathrm{Cu}, 403 \mu \mathrm{g} \mathrm{L}^{-1} \mathrm{Cd}$, $255 \mu \mathrm{g} \mathrm{L}^{-1}$; As, $235 \mu \mathrm{g} \mathrm{L}^{-1}$; Ni, $67 \mu \mathrm{g} \mathrm{L}^{-1}$; Co, $55 \mu \mathrm{g} \mathrm{L}^{-1} ; \mathrm{Sb}, 7 \mu \mathrm{g} \mathrm{L}^{-1}$; and $\mathrm{Hg}, 42 \mathrm{ng} \mathrm{L}^{-1}$,
\end{abstract}

K. W. Torrance ( $\square)$

University of Strathclyde, Glasgow, UK

e-mail: keith.w.torrance@strath.ac.uk

\section{S. D. Redwood}

Consulting Geologist, Panama, Panama

e-mail: mail@sredwood.com

\section{A. Cecchi}

Gran Colombia Gold Corp., Medellín, Colombia

e-mail: acecchi@grancolombiagold.com exceeding World Health Organization drinking water guidelines. In addition, arsenic speciation was conducted in-situ and indicated that $91-95 \%$ of inorganic arsenic species is in the form of $\mathrm{As}(\mathrm{V})$. Spatial analysis of the data suggests that entables processing ore for artisanal miners are the main contributor to water pollution, with high sediment loads, alkalinity and elevated concentrations of dissolved arsenic, cadmium, mercury and lead, caused by the processing of gold-bearing sulphides in the entables. Geochemical data from surface water were compared to a comprehensive data set of whole rock analyses from drill core and channel samples from the deposit, indicating that the deposit is significantly enriched in gold, silver, lead, zinc, arsenic, antimony, and cadmium compared to crustal averages, which is reflected in the surface water geochemistry. However, elevated mercury levels in surface water cannot be explained by enrichment of mercury in the deposit and strongly suggest that mercury is being added to concentrates during ore processing to amalgamate fine gold.

Keywords Marmato - Water quality - Artisanal and small-scale gold mining $\cdot$ Colombia $\cdot$ Arsenic speciation · Mercury 


\section{Introduction}

Colombia has a long and rich history of gold mining, dating back to the pre-Colonial era (Brooks et al., 2016). Gold mining is an important economic driver in the impoverished rural regions in Colombia, with around 300,000 miners working in the artisanal and small-scale gold mining (ASGM) sector on a mainly subsistence basis, producing an estimated 54 metric tonnes (Mt) of gold annually (Cordy et al., 2011). Many of these mines operate illegally under Colombian law, without valid mining claims, property title or environmental permits. However, as these mines represent one of the few sources of employment in rural areas, they are generally tolerated by the authorities. The improved security situation in Colombia has made it an active exploration target for foreign mining companies.

It is known that water quality in the Marmato district is impacted by mining; Prieto analysed waters in the Marmato District (G. Prieto, 1998) and reported appreciable quantities of dissolved metals, including $\mathrm{Zn}, \mathrm{Cd}, \mathrm{Cu}$, and As, with concentrations of dissolved solids up to $39,000 \mathrm{mg} \mathrm{L}^{-1}$. The purpose of this study was to document the geochemistry of surface water around Marmato, to determine the types of metal pollutants present, and to define their spatial relationship to artisanal mining and ore processing.

The town of Marmato $\left(5.47^{\circ} \mathrm{N}, 75.60^{\circ} \mathrm{W}\right)$ is in the Caldas Department of Colombia, about $80 \mathrm{~km}$ south of Medellin (Fig. 1). Marmato has been a centre of hard rock gold mining since its founding by the Spanish conquistadors in 1532, although gold in the area was exploited in pre-Colonial times by the Quimbaya people (Redwood, 2011). In 2012, approximately 2000 residents were directly employed in mining and ore processing out of a total municipal population of 10,000 , with numerous small-scale mines and adits around the town and further up Marmato Mountain. There is one large-scale modern underground mine at an elevation of $1180 \mathrm{~m}$, operated by Mineros Nacionales S.A., a subsidiary of Caldas Gold Corporation. An estimated 1.75-2.25 million ounces (Moz.) of gold was recovered from the Marmato district by 2011 (Redwood, 2011), but the district contains additional large, low-grade ore bodies that could be economically mined by bulk methods.

Marmato is situated at a mean elevation of $1,300 \mathrm{~m}$ on a steep hillside above the valley of the Rio Cauca, which flows northward towards the Caribbean. The district is readily accessible by road, being connected to the Pan-American Highway by a short length of mostly paved road. The terrain is exceptionally steep, rising over $600 \mathrm{~m}$ in $2 \mathrm{~km}$, so landslides are a frequent problem after heavy rain, blocking roads and damaging property within the town. Marmato has an equatorial climate, described as moist tropical climate, 'Am' by the Köppen and Geiger classification (Peel et al., 2007). Temperatures are warm year-round, with maximum temperatures ranging from 28.7 to $31.6{ }^{\circ} \mathrm{C}$, and minimum temperatures in the range of 17.4-18.7 ${ }^{\circ} \mathrm{C}$ (Knight Piésold Consulting, 2012). The average annual rainfall is $1889 \mathrm{~mm}$ per year, with drier periods in January, when sampling was carried out, and July (Knight Piésold Consulting, 2012). Wetter periods are in typically in spring and fall.

Marmato Mountain has been an exploration target of Gran Colombia Gold Corporation who originally defined open pit resources in the measured and indicated categories estimated at $11.8 \mathrm{Moz} \mathrm{Au}$ and 80.3 Moz Ag in 409.7 Mt of ore grading $0.90 \mathrm{~g} / \mathrm{t} \mathrm{Au}$ and $6.1 \mathrm{~g} / \mathrm{t} \mathrm{Ag}$ (Parsons \& Armitage, 2012). Gran Colombia Gold originally proposed developing an open pit mine, but in 2017, their focus switched to evaluate underground bulk mining potential following discovery of the Marmato Deeps deposit. The current combined underground resource comprises $39.40 \mathrm{Mt}$ at $3.20 \mathrm{~g} / \mathrm{t} \mathrm{Au}$ and $8.7 \mathrm{~g} / \mathrm{t} \mathrm{Ag}$ in the measured and indicated categories (4.09 Moz Au and 11.05 Moz Ag) plus $26.40 \mathrm{Mt}$ at $2.60 \mathrm{~g} / \mathrm{t} \mathrm{Au}$ and $4.4 \mathrm{~g} / \mathrm{t} \mathrm{Ag}$ inferred (2.17 Moz Au and 3.73 Moz Ag) in veins, "underground porphyry" (veinlets) and Deeps deposits (Parsons et al., 2020).

ASGM and ore processing are the most visible sources of water pollution around Marmato. There several hundred artisanal mines around Marmato, exploiting gold-rich pyrite veins in the upper portion (Zona Alta) of Marmato Mountain. A typical smallscale mine consists of a single narrow adit tunnelled into the hillside to a length of $100 \mathrm{~m}$ or less, following a gold-rich pyrite vein. As most mines lack basic ventilation, these adits do not extend very deep into the hillside. The sulphide-rich ore is manually mined from adits and loaded into ore carts, which are pushed to the mine entrance for loading on to trucks or buckets on aerial cable-ways for transport to the ninety or so local processing mills, called entables, as shown in Fig. 2. 


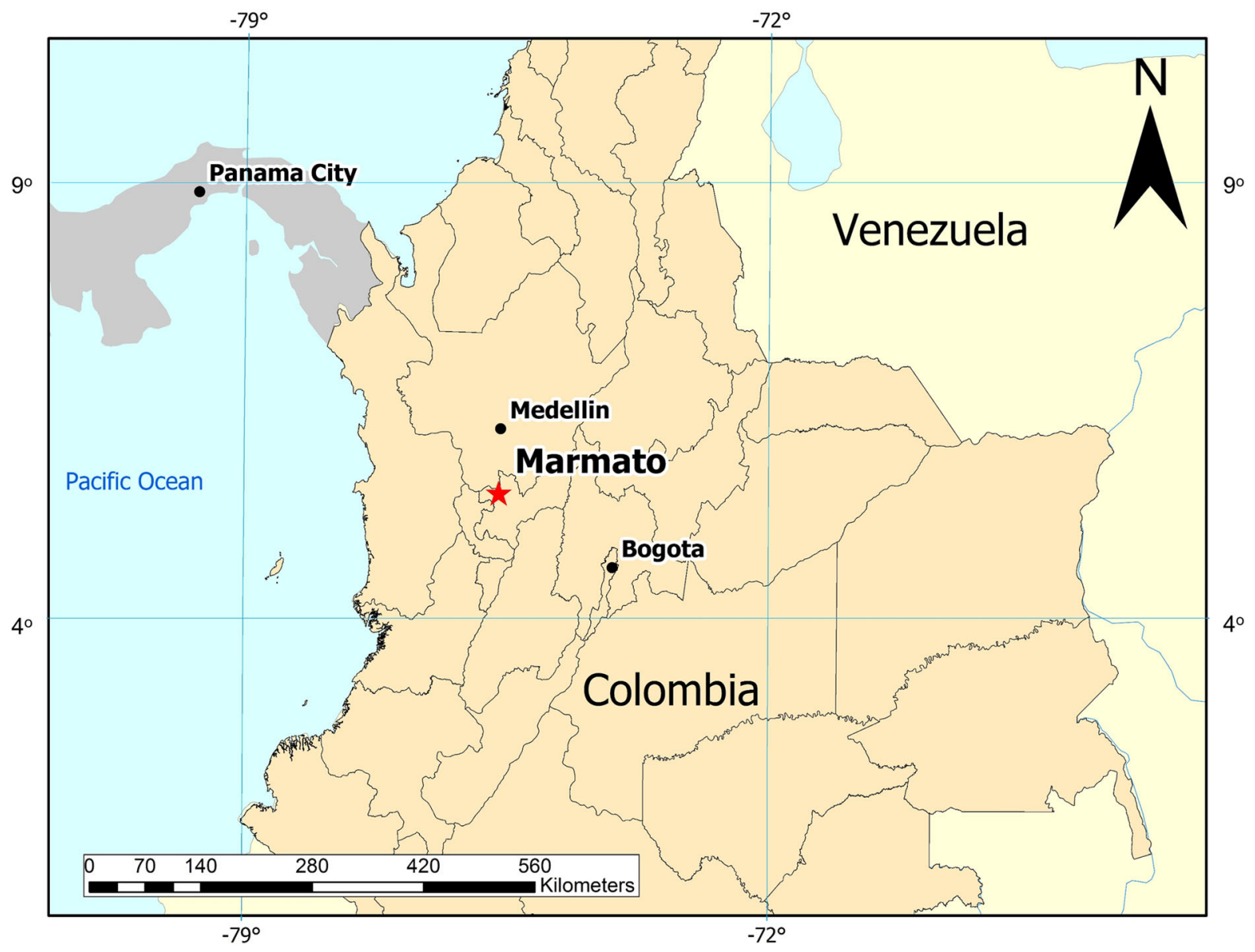

Fig. 1 Large-scale map of Colombia showing the location of the Marmato mining district in Caldas Department, Colombia

At the entables, the ore is crushed, then finely ground using small ball mills, known as cocos, to separate free gold and gold-bearing pyrite from the rock gangue. Denser gold flakes and sulphides are concentrated by gravimetry using cyclones and Wilfley tables (Fig. 2c). Gold is recovered from the concentrate by physical processes and by mercury amalgamation. Tailings from the enrichment processes are subsequently treated with sodium cyanide solution, which forms a complex with any remaining gold in the ore according to the Elsner equation (Eq. 1), allowing additional recovery.

$$
\begin{aligned}
4 \mathrm{Au}+8 \mathrm{NaCN}+\mathrm{O}_{2}+2 \mathrm{H}_{2} \mathrm{O} \rightleftarrows & 4 \mathrm{Na}\left[\mathrm{Au}(\mathrm{CN})_{2}\right] \\
& +4 \mathrm{NaOH}
\end{aligned}
$$

The addition of sodium cyanide to the milled ore creates an effluent that is highly alkaline; sodium hydroxide is also added to maintain a high $\mathrm{pH}$ to favour cyanide complexation and suppress toxic hydrogen cyanide generation. Effluent from processing is discharged directly to drainage channels without basic treatment or settling ponds. This is the most visible source of pollution entering the streams that flow down the mountain into the Rio Cauca. Downgradient of each entable is a distinctive Prussian blue stain caused by the formation of ferrocyanide complexes as the waste effluent is discarded (Fig. 3).

By-products from the milling and recovery process are discharged as a grey slurry (Fig. 4). A suspended sediment load of $40 \mathrm{~g}$ of sediment per liter was measured in one sample, downstream of the entables. In addition to the adit mines, small numbers of artisanal miners (barequeros) work the streams using pans, sluice boxes and riffle boards to recover any gold overlooked during processing (Fig. 4). 

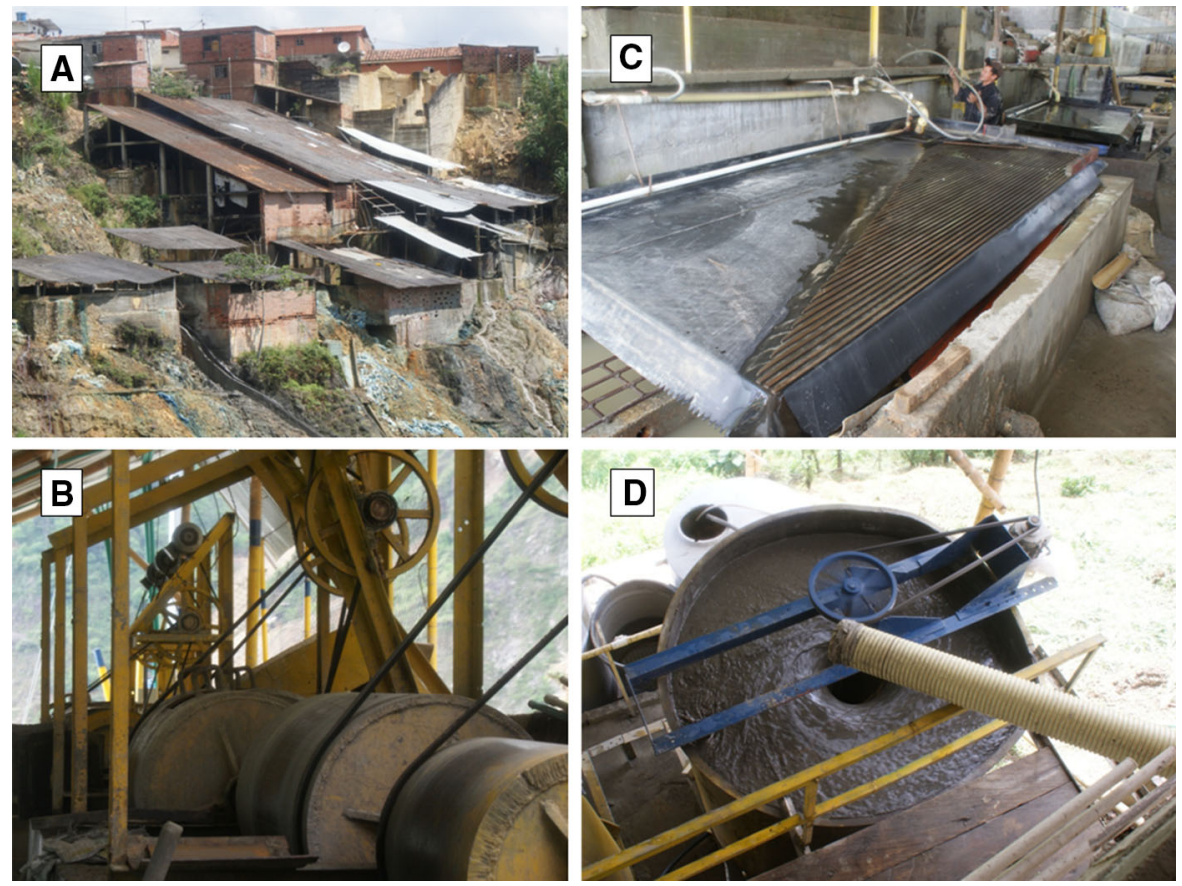

Fig. 2 a Gold ore processing in an entable in Marmato. b Ore is first crushed by jaw crusher and then (b) ground in small ball mills called cocos. $\mathbf{c}$ Gold and auriferous pyrite are separated by

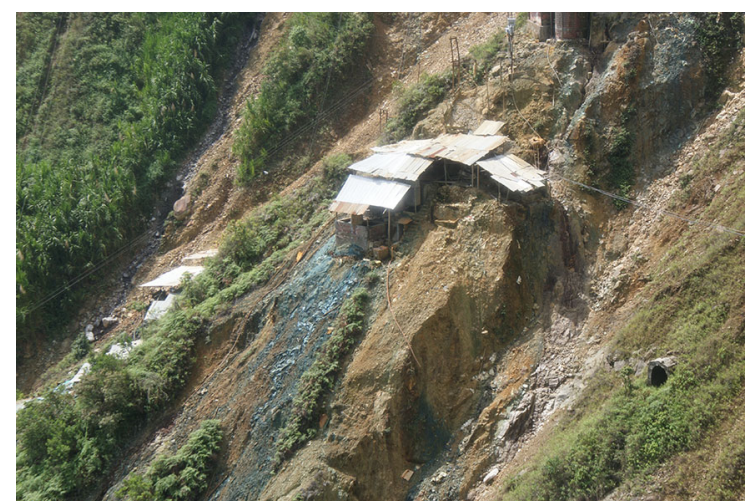

Fig. 3 A small entable near Marmato, Colombia, built on a precarious slope to process gold ore. Note the distinctive blue ferrocyanide staining from cyanide discharges from the mill. A small adit is visible in the right foreground

With an improving security situation, the Marmato district has attracted the attention of international mineral exploration companies looking to employ large-scale modern bulk mining methods with efficient gold recovery technologies. Gran Colombia Gold Corporation is exploring and developing the Marmato deposit and filed a NI 43-101 with the gravity using a Wilfley table to concentrate the denser gold and pyrite grains. d Tailings are further concentrated in cyclones, then treated with cyanide to dissolve the remaining gold

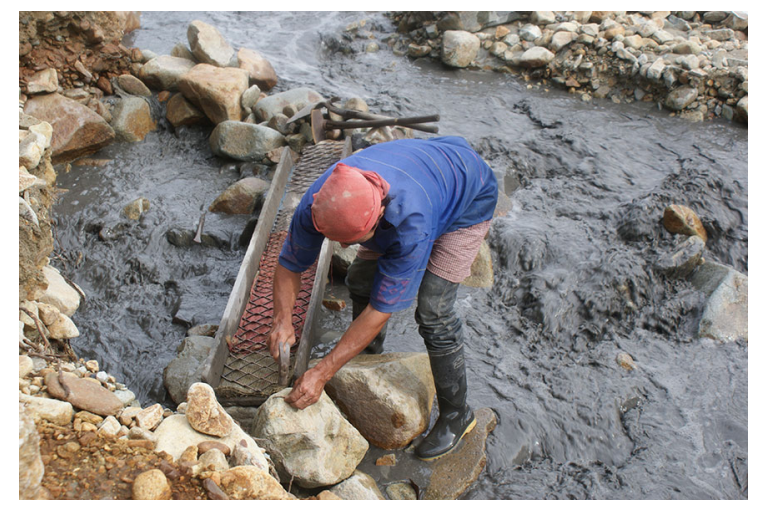

Fig. 4 A barequero working a sluice box in Qda. Cascabel at its confluence with the Rio Cauca. Note the high quantities of sediment in the creek from slurry discharged from the entables

Toronto Stock Exchange in 2012 (Parsons \& Armitage, 2012), which included an outline plan for a large open pit mine. This filing included preliminary environmental baseline studies. In October 2017, Gran Colombia Gold (Gran Colombia Gold Corp. press release, 4 October 2017) announced that they plan to develop the Marmato deposit as an expansion of their existing underground mine and released a 
preliminary economic assessment in 2019 (Parsons et al., 2019) and a pre-feasibility study in 2020 (Parsons et al., 2020), as well as spinning out the project into a new company, Caldas Gold Corporation. A consequence of this decision is that Marmato will not have to relocate as originally proposed and that artisanal gold mining within the previously planned open pit boundary will continue.

Marmato lies within the Romeral Terrane, an oceanic terrane of probable Late Jurassic to Early Cretaceous age that was accreted to the continental margin along the N-S trending Romeral Fault in the Aptian. This is partly covered by Neogene sediments and volcanic rocks, into which the composite Marmato stock was intruded. Gold mineralization is hosted by a composite andesite to dacite porphyry and is late stage, post-intrusion. Five porphyry pulses have been identified, named P1 to P5 from oldest to youngest. The age of the porphyry intrusions is bracketed by laser ablation ICP-MS ${ }^{206} \mathrm{~Pb} /{ }^{238} \mathrm{U}$ zircon dates of the $\mathrm{P} 1$ dacite stock of $6.576 \pm 0.075$ million years $(\mathrm{Ma})$ and P5 dacite dikes of $5.75 \pm 0.11 \mathrm{Ma}$ (Santacruz et al., ). The age of mineralization was dated by ${ }^{40} \mathrm{Ar} /{ }^{39} \mathrm{Ar}$ analyses of adularia in veins with plateau ages between $6.95 \pm 0.02 \mathrm{Ma}$ and $5.96 \pm 0.02 \mathrm{Ma}$ (Santacruz et al., 2018). Mineralization is structurally controlled with dominant NW and WNW trends, which developed from reactivated basement structures and as Riedel shears under WNW-ESE compression in a sinistral transpressional shear system. Mineralization extends over $1400 \mathrm{~m}$ vertically and is open at depth. Two main zones of mineralization have been identified. The Upper Zone (Fig. 5) between 1600 and $900 \mathrm{~m}$ above sea level (m.a.s.1.), mainly comprises massive, sulphide-rich, relatively quartz-poor, goldbearing base metal veins and veinlets with sericiteillite-smectite-ankerite-pyrite wall-rock alteration which overprints pervasive propylitic alteration. This zone has a mineral assemblage of pyrite-arsenopyriteFe rich sphalerite (marmatite)-pyrrhotite-chalcopyrite and electrum (average 65\% Au, 35\% Ag). The Lower Zone, below 900 m.a.s.l. and is still open at depth below 200 m.a.s.1., comprises sulphide and quartzrich veinlets and minor veins, with a mineral assemblage characterized by pyrrhotite-chalcopyrite-bismuth minerals and free gold (average 94\% Au, 6\% Ag).

\section{Materials and methods}

Surface water quality measurements

For this study, twenty sample sites in streams were selected across the district based on their proximity to active mines and entables, as shown in Fig. 6. Streams originate as springs and seeps at higher elevations, flowing from west to east into the Rio Cauca, but are largely fed by precipitation with minimal baseflow during dry seasons (JBR Environmental Consultants Inc., 2011). Water samples were collected over two days in January 2012, and their locations were determined using a Garmin Model Oregon 450 global positioning unit.

Field data are presented in Appendix, Table 2. Surface water samples were collected at each sampling point (Fig. 6), following the protocols previously described (Torrance et al., 2012a). Water parameters, including temperature, $\mathrm{pH}$, conductivity, and oxygen reduction potential (ORP), were measured at each location using a Hanna HI9828 multi-parameter meter. Alkalinity was measured in the field using a KI-9810 CHEMetrics Titrets ${ }^{\circledR}$ titration kit.

Arsenic speciation determination

The Marmato deposit has characteristics of an intermediate sulfidation epithermal system (Santacruz et al., 2014), which usually has a spatially wide arsenic signature. An additional goal of this investigation was to characterize arsenic speciation in surface water which may control its mobility. A simple field technique was used to separate arsenite species, [As(III)], and arsenate species, [As(V)], as first proposed and qualified by Ficklin (Ficklin, 1983), using a strong anion-exchange resin. An updated method (Wilkie \& Hering, 1998) was developed with further modifications (Haque \& Johannesson, 2006; Munk et al. 2011; Torrance et al., 2012a). Organic arsenic compounds may elute with As(III) and potentially skew the speciation (Miller, 2000), but is unlikely to be a concern with mineral-derived arsenic sources. Other authors (Issa et al., 2010) recommended pre-concentration of As(III) after separation in samples where $\mathrm{As}(\mathrm{V})$ dominates, but this was not found to be an issue at Marmato, where As(III) is always present above detectable limits. 


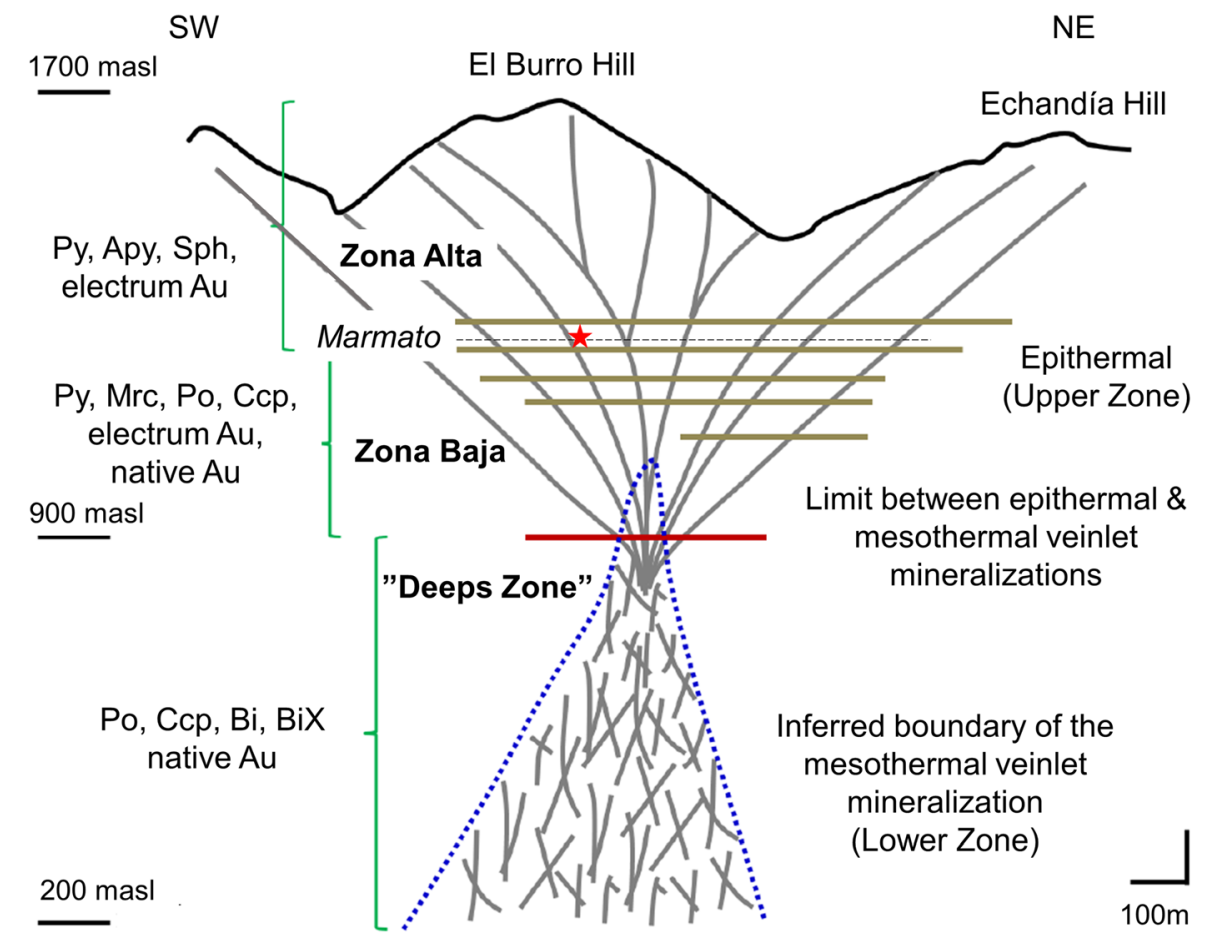

Fig. 5 Cross section of the Marmato deposit. Adapted from (Santacruz et al., 2018), showing the different mining zone. Abbreviations: Py—pyrite; Ccp—chalcopyrite; Po—pyrrhotite;
Apy—arsenopyrite; Sph—sphalerite (marmatite); Mrc-marcasite; $\mathrm{Bi}$ - bismuth; $\mathrm{BiX}$ — bismuth minerals; $\mathrm{Au}$ - gold

B

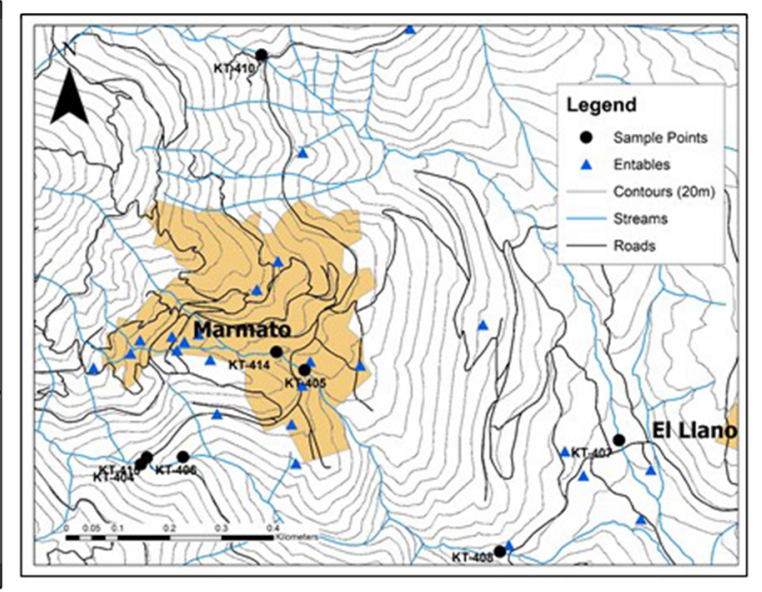

Fig. 6 a Map of the Marmato district, Colombia showing the location of all sample collection points and entables. b. Sampling locations around the city of Marmato

In the field, a 50-mL sample for As speciation was filtered from the bulk sample into a pre-cleaned $50-\mathrm{mL}$ HDPE tube, containing $100 \mu \mathrm{L}$ of ultra-pure nitric acid. This was immediately passed through a PolyPrep ${ }^{\circledR}$ anion-exchange column, prepared in $10 \mathrm{~mL}$,
$0.8 \times 4 \mathrm{~cm}$ Poly-Prep ${ }^{\circledR}$ columns, purchased from Bio-Rad Laboratories (Hercules, CA). The columns were filled with an analytical grade anion-exchange resin Bio-Rad AG® 1-X8 (50-100 mesh, chloride form), which had been converted in bulk to the acetate 
form, replacing the $\mathrm{Cl}^{-}$function group with an acetate group. Conversion of the 1-X8 resin from the chloride form to the acetate form was accomplished in the laboratory by washing $50 \mathrm{~g}$ resin with $150 \mathrm{~mL}$ of $1 \mathrm{M}$ $\mathrm{NaOH}$ solution (J. T. Baker, Phillipsburg, NJ), rinsing with NANOpure ${ }^{\mathrm{TM}}$ water and repeating two times until the $\mathrm{pH}$ of the rinse was neutral. The resin was then washed with approximately $150 \mathrm{~mL}$ of $1 \mathrm{M}$ acetic acid (BDH Aristar Ultra) a total of four times and rinsed with NANOpure ${ }^{\mathrm{TM}}$ water until neutral after each step. This quantity was sufficient to pack approximately twenty-five $0.8 \times 4 \mathrm{~cm}$ Bio-Rad Poly-Prep ${ }^{\circledR}$ ion exchange columns, at $2 \mathrm{~mL}$ per column, which were stored at $4^{\circ} \mathrm{C}$ before use.

An aliquot, at a $\mathrm{pH}$ of less than 3 , was passed through the column in increments of $5 \mathrm{~mL}$ until all the sub-sample had passed through and collected in a $60 \mathrm{~mL}$ HDPE bottle. As the sample passed through the column, oxy-anionic $\mathrm{As}(\mathrm{V})$ species, such as $\mathrm{H}_{2} \mathrm{AsO}^{4-}$, were exchanged with the acetate functional group in the resin, while neutral-charged As(III) species passed through the column. This allowed the quantities of both As species present in the sample to be determined by comparison of the total dissolved As analysis of both aliquots by ICP-MS. Samples were stored at $4{ }^{\circ} \mathrm{C}$ in the dark until analysis. Duplicate samples were taken to verify the quality of the data. A field blank (KT-419) was processed with the samples in the field and showed no elevated metals, except for $\mathrm{Cu}$ ( $\left.3.7 \mu \mathrm{g} \mathrm{L}^{-1}\right)$.

Anions were measured using a Dionex ${ }^{\circledR}$ BioIC ion chromatography instrument. Total metal concentrations were determined by inductively coupled plasma mass spectrometry (ICP-MS), using an Agilent $7700 \times$ instrument. Total $\mathrm{Hg}$ was determined using a PS Analytical Millennium Merlin Atomic Fluorescence Spectrometer (AFS).

\section{Results and discussion}

Concentrations of selected dissolved metals in surface water are presented in Appendix (Table 3). The average dissolved metal concentrations ${ }^{1}$ from streams

\footnotetext{
$\overline{1}$ Analytical results from Canalon de la Iglesia (KT-409) were excluded from the calculated average as dissolved metal concentrations are almost an order of magnitude higher than from other sampling points.
}

impacted by ore processing discharges were: $\mathrm{Zn}$, $78 \mathrm{mg} \mathrm{L}^{-1} ; \mathrm{Pb}, 0.43 \mathrm{mg} \mathrm{L}^{-1} ; \mathrm{Cu}, 403 \mu \mathrm{g} \mathrm{L}^{-1} \mathrm{Cd}$, $255 \mu \mathrm{g} \mathrm{L}^{-1}$; As, $235 \mu \mathrm{g} \mathrm{L}^{-1}$; Ni, $67 \mu \mathrm{g} \mathrm{L}^{-1}$; Co, $55 \mu \mathrm{g} \mathrm{L}^{-1}$; $\mathrm{Sb}, 7 \mu \mathrm{g} \mathrm{L}^{-1}$; and $\mathrm{Hg}, 42 \mathrm{ngL}^{-1}$. For those metals that the World Health Organization (WHO) has established drinking water guidance (WHO, 2011), average dissolved Cd concentrations are 80 times the WHO guidance value of $3 \mu \mathrm{g} \mathrm{L}^{-1}$; average dissolved $\mathrm{Pb}$ concentrations are 43 times the WHO guidance value of $10 \mu \mathrm{g} \mathrm{L}^{-1}$, and average dissolved As concentrations are 23 times the WHO guidance value of $10 \mu \mathrm{g} \mathrm{L}^{-1}$. These represents a significant impairment of water quality rendering it unsuitable for drinking water and livestock watering.

\section{Arsenic}

Latin America has well documented occurrences of arsenic exposure including previous studies from Marmato (Bundschuh et al., 2012). Total dissolved As in surface water ranged from 6 to $3521 \mu \mathrm{g} \mathrm{L} \mathrm{L}^{-1}$, with higher values in water that was visibly affected by run-off from ore processing. XRD analysis of solid particulates filtered from stream water indicates a high proportion of pyrite (Fig. 7), and it seems likely that As enters the watershed from the dissolution of pyrite and arsenopyrite during ore concentration. The upper zone of the deposit, Zona Alta, which is worked exclusively by small-scale miners, contains more arsenopyrite than the lower Zona Baja (Santacruz et al., 2018).

Dissolved arsenic concentrations in the unpolluted Quebrada (Qda.) Los Indios are also elevated at 90-140 $\mu \mathrm{g} \mathrm{L}^{-1}$ which suggests that background As concentration is naturally elevated in the region. This is confirmed by whole rock assays determined during the exploration program, which had an average As concentration of $65 \mathrm{ppm}$.

Arsenic concentrations exceed the WHO's guidance value for drinking water of $10 \mu \mathrm{g} \mathrm{L}^{-1}$ at all but one sampling point. Figure 8a shows total As concentrations around Marmato. Colombia has additional maximum thresholds for arsenic in irrigation water $\left(100 \mu \mathrm{g} \mathrm{L}^{-1}\right)$ and for livestock water supply of $200 \mu \mathrm{g}$ $\mathrm{L}^{-1}$ (Alonso et al., 2014). Five of the water samples collected exceeded the higher threshold for livestock water. 

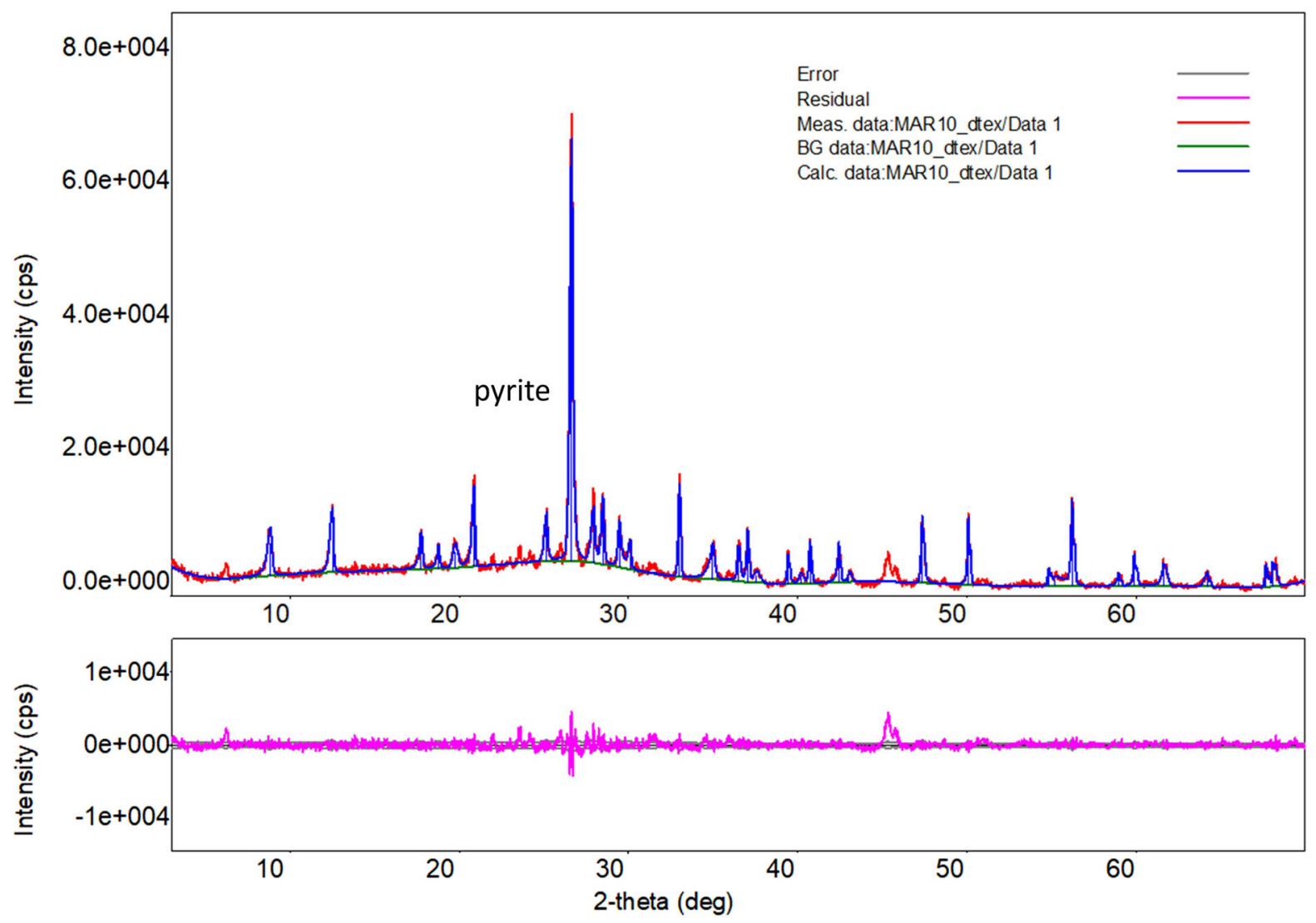

Fig. 7 Powder XRD pattern of suspended sediment collected at KT-405, showing dominant peaks for pyrite

A

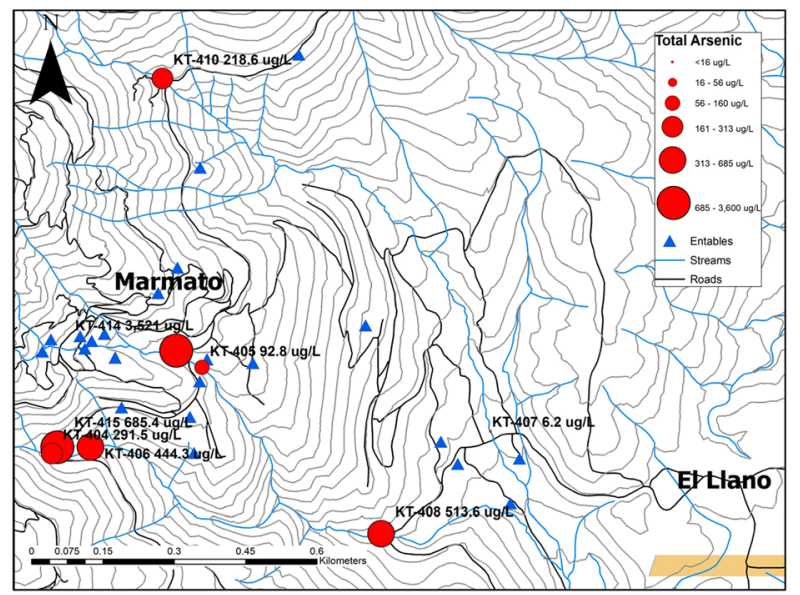

B

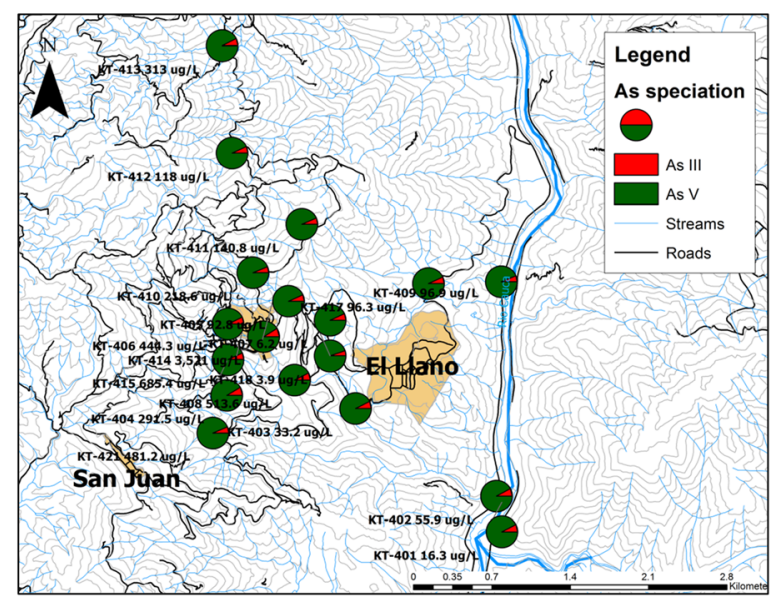

Fig. 8 a Total arsenic concentration is surface water at Marmato. b Arsenic speciation at Marmato. The dominant species is arsenate, $\operatorname{As}(\mathrm{V})$ 
Arsenic speciation

Dissolved arsenic is stable under normal Eh and $\mathrm{pH}$ conditions in streams as either arsenite, As(III), or arsenate species, As(V) (Cullen \& Reimer, 1989). It has been noted that there are no published arsenic speciation results published from sites in Colombia (Alonso et al., 2014). In this study, field separation of arsenic species in water was conducted as previously described by passing a separate aliquot through disposable chromatographic columns to separate inorganic As(III) species, with later analysis by ICPMS. Anionic arsenate species, having a negative charge, were retained in the resin, while neutral arsenite species passed through the column unimpeded.

The results, which are shown in Table 1, indicated that 91 to $95 \%$ of the arsenic species is in the form of As(V), with little spatial variation (Fig. 8b). This is consistent with the measured $\mathrm{pH}$ and Eh values, which predict the dominance of the more oxidized $\mathrm{As}(\mathrm{V})$ form. It is also further evidence that there is minimal groundwater interaction with the streams, which would have an As(III) signature due to reducing conditions within the subsurface.

Qda. Cascabel has some of the highest concentrations of dissolved total arsenic and is fed by smaller tributaries, e.g., Canalon de la Iglesia, into which discharges from entables in Marmato are most severe.

\section{Cadmium}

Cadmium is an extremely toxic metal even at low concentrations, attacking the kidney and causing itaiitai disease, an osteomalacia with various grades of osteoporosis accompanied by severe renal tubular disease from chronic exposure (WHO, 2011). Total dissolved $\mathrm{Cd}$ in the Marmato samples ranged from 0.2 to $833 \mu \mathrm{g} \mathrm{L}^{-1}$. For comparison, the WHO guidance value for drinking water is $3 \mu \mathrm{g} \mathrm{L}^{-1}$. Cd concentrations are below $1 \mu \mathrm{g} \mathrm{L}^{-1}$ in Qda. Los Indios and the Rio Cauca, indicating background levels that are near normal. $\mathrm{Cd}$ is enriched within the deposit by a factor of 100 compared to crustal averages (Table 4). It seems likely that $\mathrm{Cd}$ is released from the mineral sphalerite $(\mathrm{ZnS})$ which is abundant in the ore veins and is crushed with the ore; dissolved $\mathrm{Cd}$ and $\mathrm{Zn}$ concentrations show a strong correlation $\left(R^{2}=0.887\right)$. Figure 9a shows $\mathrm{Cd}$ aqueous concentrations in the vicinity of Marmato.
Other trace metals, such as gallium and indium, were present at detectable levels which may also originate the minerals sphalerite $(\mathrm{ZnS})$ and marmatite $((\mathrm{Fe}) \mathrm{ZnS})$, which are abundant in the mineralized zones within Marmato Mountain.

Lead

Dissolved lead $(\mathrm{Pb})$ concentrations ranged from 4.4 to $4,880 \mu \mathrm{g} \mathrm{L}^{-1}$, compared to the WHO guidance of $10 \mu \mathrm{g} \mathrm{L}^{-1}$. The highest $\mathrm{Pb}$ concentrations corresponded to streams with the highest levels of observed suspended sediment, such as Canalon de la Iglesia (KT-415). Figure 9b shows $\mathrm{Pb}$ levels in stream water around Marmato. Lead in surface water probably originates from the dissolution of the mineral galena $(\mathrm{PbS})$, which is concentrated during ore processing. Concentrations of lead are higher in streams that have a $\mathrm{pH}$ of $>5.5$ and $<7.5$.

\section{Mercury}

Mercury (Hg) was detected in several samples from Qda. Cascabel (Fig. 9d), with concentrations up to $142 \mathrm{ng} \mathrm{L}^{-1}$, which is well above background levels, which are below detection limits $\left(10 \mathrm{ng} \mathrm{L}^{-1}\right)$. WHO has set a guideline of $6 \mu \mathrm{g} \mathrm{L}^{-1}$ for inorganic mercury in drinking water (WHO, 2011), but this is rarely exceeded as inorganic mercury compounds are poorly soluble. Ingestion of methyl mercury is a more potent exposure pathway; analysis of fish tissue is a more appropriate matrix for assessing mercury impacts in a watershed. Nevertheless, the concentrations of $\mathrm{Hg}$ at Marmato are comparable to dissolved concentrations reported from a stream traversing an abandoned mercury mine in Alaska (Torrance et al., 2012b).

Leaching studies of representative mining waste carried out to determine the acid rock drainage (ARD) potential at Marmato indicated a maximum dissolved $\mathrm{Hg}$ concentration of $10 \mathrm{ng} \mathrm{L}^{-1}$ in the leachate from a single sample out of 20 tested (Knight Piésold Consulting, 2012). It seems therefore unlikely that dissolved $\mathrm{Hg}$ in the streams around Marmato originates from naturally occurring minerals in the ore and that $\mathrm{Hg}$ is more likely to have been added during ore processing to enhance gold recovery. This is corroborated by the lack of enrichment of $\mathrm{Hg}$ in the deposit as shown by multi-element analyses of drill core samples with a mean value of $0.886 \mathrm{ppm}$ and a range 
Table 1 Arsenic speciation in water samples at Marmato, Colombia, determined by AFS

\begin{tabular}{lllcll}
\hline Sample & Location & Total As $\mu \mathrm{g} \mathrm{L}^{-1}$ & As (III) $\mu \mathrm{g} \mathrm{L}^{-1}$ & As (V) $\mu \mathrm{g} \mathrm{L}^{-1}$ & $\%$ As (III) \\
\hline KT-401 & Rio Cauca & 16.3 & 1.24 & 15.09 & 7.62 \\
KT-402 & Qda. Cascabel & 55.9 & 4.36 & 51.52 & 7.81 \\
KT-403 & Qda. Cascabel & 33.2 & 2.49 & 30.69 & 7.50 \\
KT-404 & Qda. Cascabel & 291.5 & 25.3 & 266.2 & 8.67 \\
KT-405 & Canalon de la Iglesia & 92.8 & 6.30 & 86.45 & 6.79 \\
KT-406 & Qda. Cascabel & 444.3 & 31.9 & 412.4 & 7.18 \\
KT-407 & Qda. Pantanos & 6.2 & 0.43 & 5.76 & 7.01 \\
KT-408 & Qda. Cascabel & 513.6 & 39.3 & 474.3 & 7.65 \\
KT-409 & Qda. Los Indios & 96.9 & 6.14 & 90.8 & 6.34 \\
KT-410 & Qda. Pantanos & 218.6 & 13.5 & 205 & 6.19 \\
KT-411 & Qda. Los Indios & 140.8 & 9.3 & 131.5 & 6.59 \\
KT-412 & Qda. Chaurquia & 118.0 & 8.19 & 109.8 & 6.94 \\
KT-413 & Qda. San Jorge & 313.0 & 23.3 & 289.7 & 7.44 \\
KT-414 & Canalon de la Iglesia & 3,521 & 312.9 & 3,208 & 8.89 \\
KT-415 & Qda. Cascabel & 685.4 & 46.7 & 638.6 & 6.82 \\
KT-416 & Rio Arquia & 160.9 & 9.41 & 151.48 & 5.85 \\
KT-417 & Qda. Los Indios & 96.3 & 6.57 & 89.69 & 6.82 \\
KT-421 & Qda. Aguas Claras & 481.2 & 30.53 & 450.63 & 6.34 \\
\hline
\end{tabular}

of $<0.005 \mathrm{ppm}$ (lower limit of detection) to $373 \mathrm{ppm}$ $(n=16,783)$, compared with a crustal average of 0.5 ppm (Fig. 10). Less than $10 \%$ of samples analysed had mercury concentrations above the crustal average.

The locations of the anomalous $\mathrm{Hg}$ sample points, shown in Fig. 9d, are not directly related to the position of the entables. This may indicate isolated mercury use by artisanal miners at some mining locations, perhaps to enhance recoveries from gold panning. No attempt was made to determine whether the $\mathrm{Hg}$ is present as inorganic mercury or as more toxic organo-mercury compounds.

Entables in the mining districts of the State of Antioquia of Colombia, north of Medellin, are known to make extensive use mercury to extract gold from ore through amalgamation (Hentschel et al., 2002; Prieto \& Gonzalez, 1998). High levels of atmospheric mercury have been recorded in Segovia, Zaragoza, and other towns in the district (Cordy et al., 2011) where the raw ore is processed, and gold refined from doré. The United Nations Environmental Program (UNEP) estimates that artisanal gold mining accounts for the release of over 1,000 metric tons of $\mathrm{Hg}$ into the environment worldwide every year (Telmer \& Veiga, 2009). Further, the monopolistic supply of mercury by gold buyers to the miners is viewed as an "agent of poverty" (Hilson \& Pardie, 2006). An inventory of mercury in Colombia for 2011 estimated that 140 metric tons of mercury are released into the environment each year from artisanal and small-scale mining (Brooks, 2012).

Not only are non-mercury gold extraction processes more environmentally friendly; gold recovery is potentially much higher (García et al., 2015). At Marmato, although there was no visible evidence of mercury use in the entables that were visited, it is understood that mercury is frequently used in the final process to extract gold from the concentrate. As confirmation, mercury was detected in some water samples at levels up to $142 \mathrm{ng} \mathrm{L}^{-1}$.

\section{Antimony}

Antimony $(\mathrm{Sb})$ concentrations in surface water ranged from below the level of detection to a maximum of $30.2 \mu \mathrm{g} \mathrm{L}^{-1}$, as compared to the WHO drinking water guidance on antimony of $20 \mu \mathrm{g} \mathrm{L}^{-1}$ (WHO, 2011). Other regulatory agencies, such as the United States Environmental Protection Agency, have set a lower Maximum Contaminant Level (MCL) for Sb of $6 \mu \mathrm{g}$ 
A

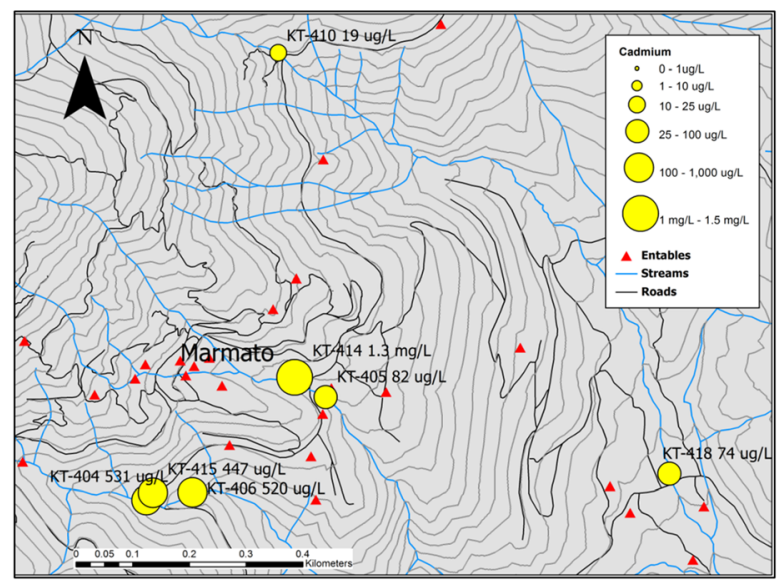

C

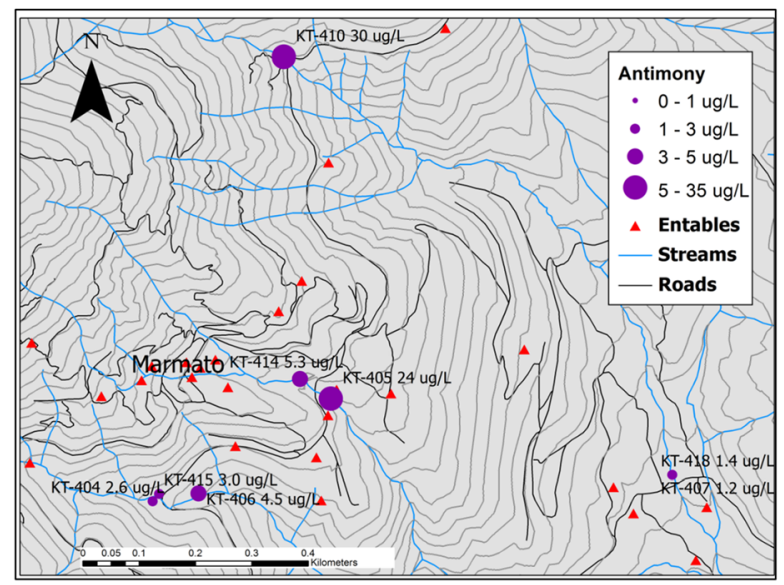

B

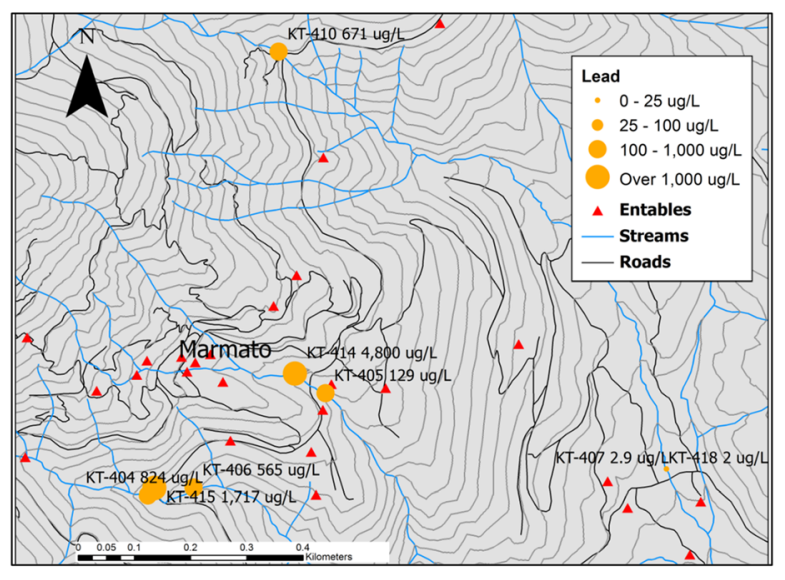

D

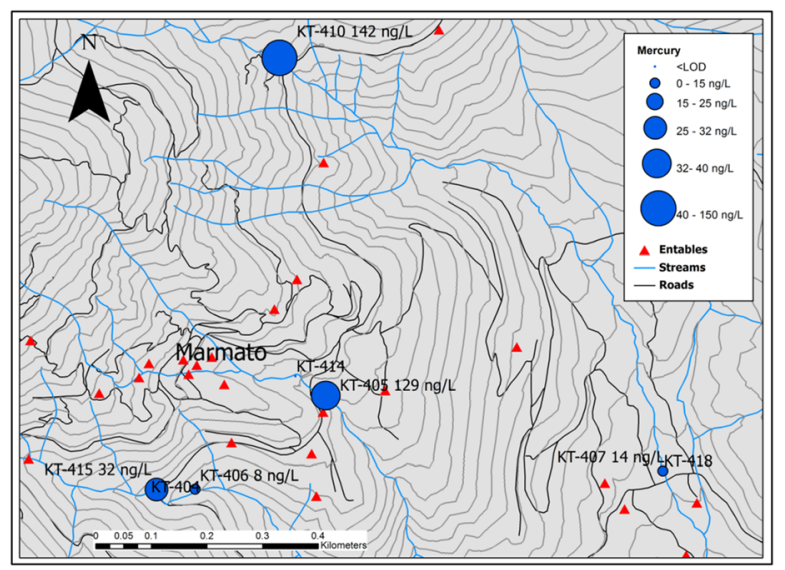

Fig. 9 Spatial relationship between dissolved metal concentrations in surface water around Marmato to the entables (red triangles). a Cadmium. b Lead. c Antimony. d Mercury

$\mathrm{L}^{-1}$. In comparison with other dissolved metals in the streams, $\mathrm{Sb}$ is not at especially elevated levels, although it is present in mineralized zones within the deposit. Figure 9c shows Sb concentrations in streams around Marmato.

\section{Other metals}

Dissolved gold is present in some water samples up to $108 \mu \mathrm{g} \mathrm{L}^{-1}$. Their sampling location downstream of the entables suggests that these high values are losses from cyanide processing of crushed gold ore. It highlights the inefficiency of the gold recovery process in the entables and the associated loss of income to the miners. Concentrations of gallium and indium were also elevated; however, indium levels may be an artefact of ICP-MS analysis, which uses indium as an internal standard. Indium and gallium most likely occur as chemical substitutions in the mineral sphalerite, which is an abundant sulphide in the deposit.

Water samples from Qda. Cascabel showed elevated rare earth elements (REEs) including $\mathrm{Nd}, \mathrm{Eu}$, $\mathrm{Gd}$, and Er. As there are no observed pegmatite veins in the complex, which are often elevated in REEs, their origin is unknown. For all samples, dissolved arsenic concentration was observed to correlate with zinc $\quad\left(R^{2}=0.68\right), \quad$ cadmium $\quad\left(R^{2}=0.65\right), \quad$ lead $\left(R^{2}=0.54\right)$, and iron $\left(R^{2}=0.43\right)$ dissolved concentrations, arsenic concentrations correlated less strongly with selenium $\left(R^{2}=0.35\right)$, cobalt $\left(R^{2}=0.34\right)$ and nickel $\left(R^{2}=0.26\right)$. There was no 

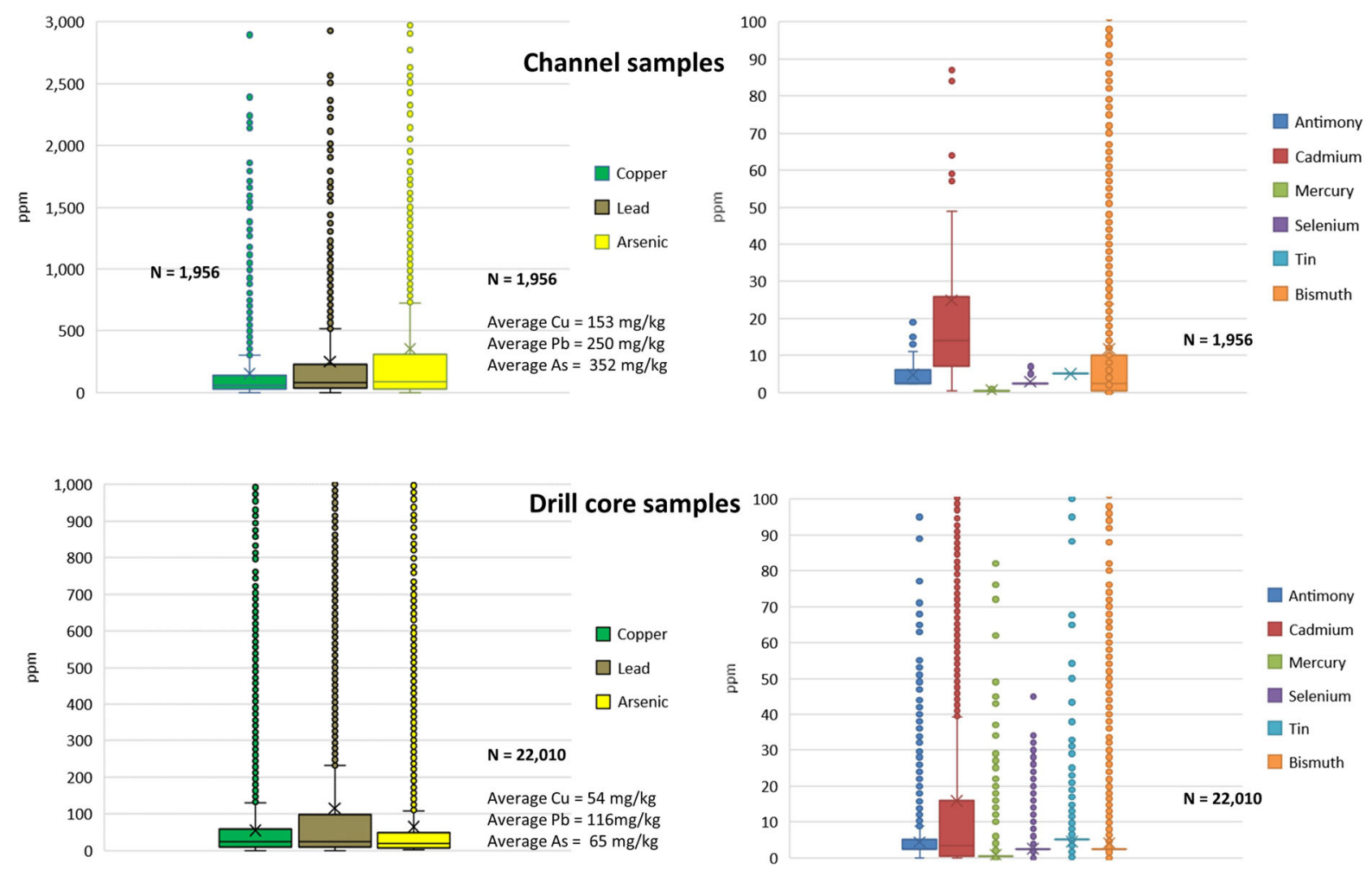

Fig. 10 Box and whisker charts showing metal concentrations by atomic absorption (AA) and ICP analytical methods in surface channel samples (top figures) and diamond drill core (bottom figures)

correlation $\left(R^{2}<0.07\right)$ of dissolved arsenic concentrations with antimony, copper, manganese, or barium. Dissolved mercury concentrations also showed no correlation with dissolved arsenic concentration, with reported concentrations of mercury above the detection limit confined to Qda. Cascabel, Qda. Pantanos, and their tributaries. Our interpretation of the spatial data is that dissolved mercury concentrations are related to clandestine mercury amalgamation within entables that discharge into these creeks.

\section{Whole rock analysis}

Elemental analysis of drill cores through the mountain is presented as box and whisker diagrams in Fig. 10 and as Appendix, Table 4. Distributions for most potentially toxic metals, including $\mathrm{As}, \mathrm{Cd}, \mathrm{Pb}$, and $\mathrm{Sb}$, are positively skewed, reflecting the elevated concentrations of these metals within the mineralized areas and their association with sulphides such as arsenopyrite, sphalerite, galena and tennantite-tetrahedrite that occur in the low to intermediate sulphidation epithermal veins. Based on average crustal abundances, metals are enriched within the mineralized zone as follows: $\mathrm{Cd}>\mathrm{Au}>\mathrm{As}>\mathrm{Ag}>\mathrm{Sb}>\mathrm{Zn}>$ $\mathrm{Hg}>\mathrm{Pb} . \mathrm{Cu}, \mathrm{Mo}, \mathrm{Cr}$, and $\mathrm{Sn}$ are enriched within the deposit by a factor of less than 2 and have neither economic value nor environmental concerns.

\section{Conclusions}

Surface water quality within the vicinity of Marmato is significantly impaired by many pollutants resulting from ASGM and gold ore processing. These impacts are as follows:

1. The disposal of milled ore slurry from the mine workings and entables visibly impacts the clarity of surface water due to very high suspended sediment loads. This renders surface water unsuitable either as a drinking water source or for agriculture.

2. Water exiting mine adits is acidic due to the oxidation of pyrite and sphalerite, with a 
minimum $\mathrm{pH}$ of 3.85 observed. Surface water downgradient of the entables has elevated $\mathrm{pH}$ (maximum $\mathrm{pH} 10.3$ ) due to the addition of caustic sodium hydroxide pellets during cyanide treatment of crushed ore to extract gold.

3. Although cyanide was not one of the analytes in this study, its presence in surface water can be inferred by the observation of blue ferrocyanide staining downgradient of the entables.

4. Sphalerite, galena, and pyrite minerals associated with gold-bearing ore release cadmium, lead, and arsenic, respectively, into solution during ore processing via oxidation and physical processes.

5. Cadmium, lead, and arsenic are present in elevated concentrations within the mineralized zone of the Marmato deposit. The naturally occurring concentrations of these toxic metals in surface waters are exacerbated by mining and ore processing. Further, mining spoil that is dumped on the steep hillside further-enhances frequent mass wasting events, such as landslides and mud flows. These impacts limit evaluation of the natural, pre-mining metal concentrations in surface waters.

6. Lead, arsenic and cadmium are present in surface water at concentrations that greatly exceed WHO guidance (WHO, 2011) for drinking water quality. Other factors, such as sediment load and alkalinity, render water from these sources unsuitable for human consumption or for irrigation.

7. The source of elevated mercury concentrations in surface water is most likely from amalgamation of ore concentrates by artisanal miners, as $\mathrm{Hg}$ is not significantly elevated in the Marmato deposit. It has been estimated that $30-50 \%$ of mercury is not recovered during amalgamation in the entables (García et al., 2015).

8. Detection of dissolved gold up to $108 \mu \mathrm{g} \mathrm{L}^{-1}$ suggests that the existing extraction methods do not recover all of the gold present in the ore. More efficient extraction technology could be introduced in Marmato that would be both environmentally friendly and more profitable for the miners.

The human health risks, both chronic and acute, related to ingestion of arsenic, cadmium and lead via drinking water are well documented and associated with mining districts (Candeias et al., 2019). Potable water for the use of Marmato residents is piped in from more distant sources unaffected by mining. In this study, a sampling location at Qda. Los Indios (KT-417) was considered as representative of background water quality, as Marmato residents use this stream as an alternative source of clean water. However, the polluted streams around Marmato discharge into the Rio Cauca, which is the main source of drinking water for several downstream communities and is further impacted by other mining and industrial activities in the region. Human health impacts from exposure to mercury from small-scale mining are linked to inhalation of mercury vapour (Gibb \& O'Leary, 2014), and to the ingestion of methyl mercury in fish and other food sources (Palacios-Torres et al., 2018; Selin, 2009), rather than ingestion via drinking water. Impacts of artisanal gold mining in similar mining communities in western Colombia are well documented (Gutierrez-Mosquera et al., 2018; Marrugo-Negrete et al., 2017).

It has been estimated that ASGM accounts for around $87 \%$ of the gold produced in Colombia (Veiga \& Marshall, 2019), which operates under a complex regulatory regime. The socio-technical interactions between large-scale and artisanal miners in Marmato have been discussed in depth (Holley et al., 2020). Gran Colombia Gold Corporation's original proposal to develop a large-scale open pit mine at Marmato caused conflict in part because the excavation of the open pit would require the relocation of the town of Marmato. Further, the removal of most of the Zona Alta to create the open pit would greatly restrict ASGM in the district. Although much of this mining is illegal under Colombian law, it is the main source of employment in Marmato.

A modern gold mine operating under a robust permitting regime with appropriate environmental controls would avoid the extreme water quality impacts observed at Marmato. If it is accepted that restriction of ASGM is neither feasible nor socioeconomically desirable, there are multiple obstacles to addressing water pollution arising from artisanal mining. The implementation of the Minamata Convention on Mercury in 2017, which was ratified by Colombia in 2019 (UN Environmental Programme, 2020), has formalized restrictions on mercury use but is unlikely to completely eliminate the practice and barriers still remain for the implementation of alternative extraction retort technologies (Bosse Jønsson et al., 2013; Clifford, 2014). A more realistic approach 
might be to encourage ore processing at a central facility (Veiga et al., 2014), instead of at the numerous small entables in the region. This would permit better environmental controls to be implemented, and the quality of the discharges to the River Cauca to be controlled and monitored.

Acknowledgements The authors wish to thank Gran Colombia Gold Corp. and Caldas Gold Corp. for permission to use the assay data from their Marmato exploration program and for covering travel costs to Marmato for Keith Torrance. Analytical results have been previously reported in a $\mathrm{PhD}$ thesis (Torrance 2012).

Author contributions Keith Torrance collected the field samples and performed the analytical analysis of the surface water samples and field arsenic speciation. Dr. Stewart Redwood authored the section on the geology of Marmato, based on his own field studies. Dr. Alessandro Cecchi logged and analysed drill core from Marmato and provided descriptions of the mineralization within the deposit.

\section{Declarations}

Conflict of interest The authors declare no conflict of interest.

Open Access This article is licensed under a Creative Commons Attribution 4.0 International License, which permits use, sharing, adaptation, distribution and reproduction in any medium or format, as long as you give appropriate credit to the original author(s) and the source, provide a link to the Creative Commons licence, and indicate if changes were made. The images or other third party material in this article are included in the article's Creative Commons licence, unless indicated otherwise in a credit line to the material. If material is not included in the article's Creative Commons licence and your intended use is not permitted by statutory regulation or exceeds the permitted use, you will need to obtain permission directly from the copyright holder. To view a copy of this licence, visit http://creativecommons.org/licenses/by/4.0/.

\section{Appendix}

See Tables 2, 3, 4 


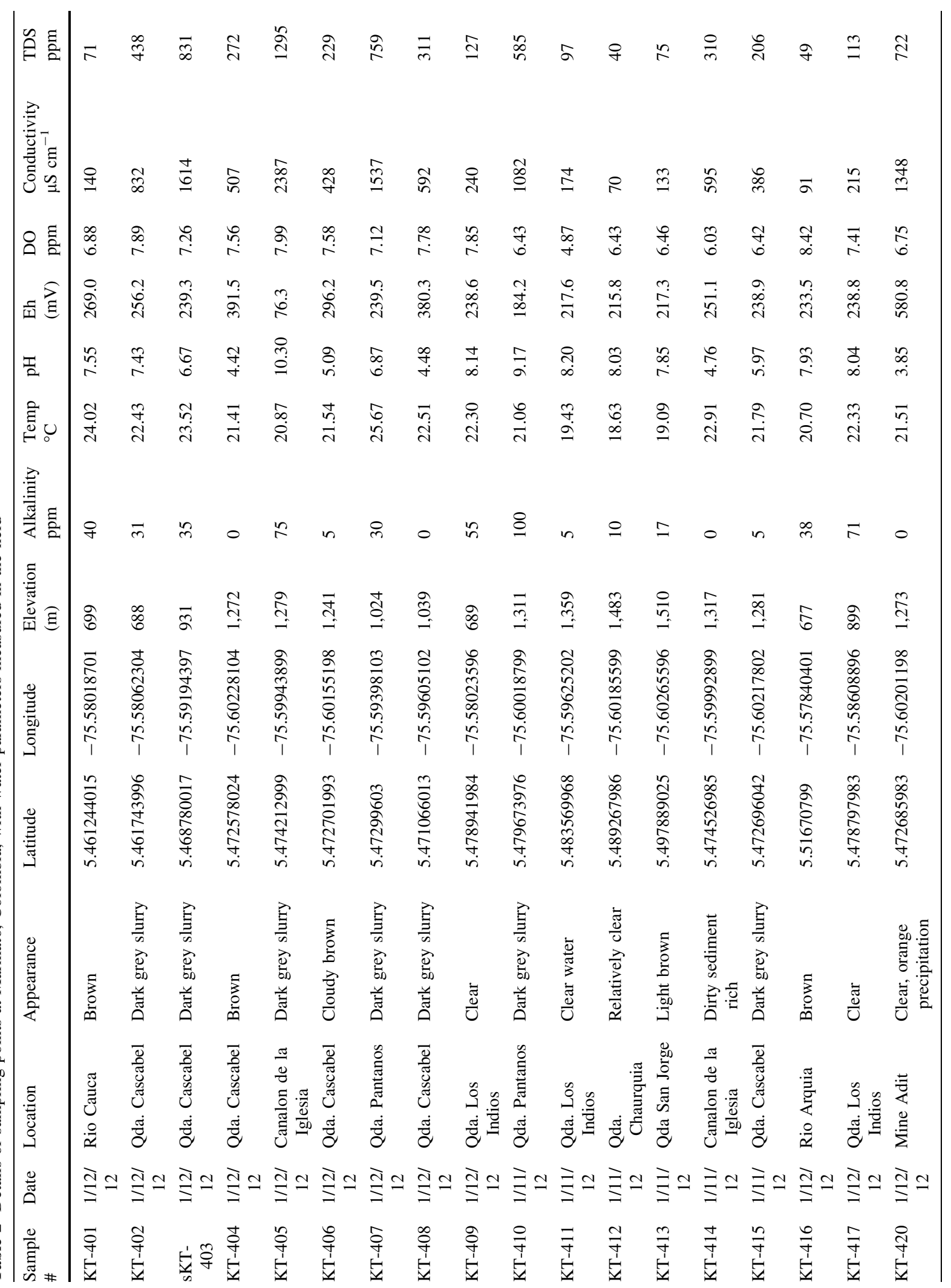


Table 3 Analysis of selected dissolved metals from Marmato, Colombia, by ICP-MS

\begin{tabular}{|c|c|c|c|c|c|c|c|c|c|c|c|c|}
\hline Sample & Location & Appearance & $\begin{array}{l}\mathrm{Co} \mu \mathrm{g} \\
\mathrm{L}^{-1}\end{array}$ & $\begin{array}{l}\mathrm{Ni} \\
\mu \mathrm{g} \\
\mathrm{L}^{-1}\end{array}$ & $\begin{array}{l}\mathrm{Cu} \\
\mu \mathrm{g} \\
\mathrm{L}^{-1}\end{array}$ & $\begin{array}{l}\mathrm{Zn} \mathrm{mg} \\
\mathrm{L}^{-1}\end{array}$ & $\begin{array}{l}\text { As } \\
\mu \mathrm{g} \\
\mathrm{L}^{-1}\end{array}$ & $\begin{array}{l}\mathrm{Cd} \\
\mu \mathrm{g} \\
\mathrm{L}^{-1}\end{array}$ & $\begin{array}{l}\mathrm{Sb} \\
\mu \mathrm{g} \\
\mathrm{L}^{-1}\end{array}$ & $\begin{array}{l}\mathrm{Au} \mu \mathrm{g} \\
\mathrm{L}^{-1}\end{array}$ & $\begin{array}{l}\mathrm{Hg}^{-1} \mathrm{~g} \\
\mathrm{~L}^{-1}\end{array}$ & $\begin{array}{l}\mathrm{Pb} \\
\mu \mathrm{g} \\
\mathrm{L}^{-1}\end{array}$ \\
\hline KT-401 & Rio Cauca & Brown & 5.1 & 26.4 & 43.0 & 0.15 & 16.3 & 0.2 & 0.2 & $<\mathrm{LOD}$ & $<\mathrm{LOD}$ & 4.4 \\
\hline KT-402 & $\begin{array}{l}\text { Qda. } \\
\text { Cascabel }\end{array}$ & $\begin{array}{l}\text { Dark grey } \\
\text { slurry }\end{array}$ & 5.9 & 18.1 & 1,129 & 0.71 & 55.9 & 4.3 & 1.8 & 6.6 & 39 & 45.6 \\
\hline KT-403 & $\begin{array}{l}\text { Qda. } \\
\text { Cascabel }\end{array}$ & $\begin{array}{l}\text { Dark grey } \\
\text { slurry }\end{array}$ & 15.0 & 27.8 & 887.8 & 4.43 & 33.2 & 25.9 & 0.5 & 7.4 & 24 & 27.3 \\
\hline KT-404 & $\begin{array}{l}\text { Qda. } \\
\text { Cascabel }\end{array}$ & Brown & 87.1 & 75.5 & 402.0 & 182.59 & 291.5 & 530.9 & 2.6 & 5.3 & $<\mathrm{LOD}$ & 823.7 \\
\hline KT-405 & $\begin{array}{c}\text { Canalon de } \\
\text { la Iglesia }\end{array}$ & $\begin{array}{l}\text { Dark grey } \\
\text { slurry }\end{array}$ & 9.3 & 60.4 & 24.9 & 28.55 & 92.8 & 82.0 & 23.5 & 108.6 & 38 & 129.1 \\
\hline KT-406 & $\begin{array}{l}\text { Qda. } \\
\text { Cascabel }\end{array}$ & $\begin{array}{l}\text { Cloudy } \\
\text { brown }\end{array}$ & 104.0 & 88.3 & 241.9 & 153.69 & 444.3 & 519.6 & 4.5 & 7.3 & 8 & 564.6 \\
\hline KT-407 & $\begin{array}{l}\text { Qda. } \\
\text { Pantanos }\end{array}$ & $\begin{array}{l}\text { Dark grey } \\
\text { slurry }\end{array}$ & 40.6 & 38.8 & 1.5 & 19.76 & 6.2 & 90.2 & 1.2 & 0.2 & 14 & 2.9 \\
\hline KT-408 & $\begin{array}{l}\text { Qda. } \\
\text { Cascabel }\end{array}$ & $\begin{array}{l}\text { Dark grey } \\
\text { slurry }\end{array}$ & 215.7 & 219.5 & 650.0 & 210.28 & 513.6 & 832.8 & 2.7 & 13.1 & $<\mathrm{LOD}$ & 319.1 \\
\hline KT-409 & $\begin{array}{l}\text { Qda. Los } \\
\text { Indios }\end{array}$ & Clear & $<$ LOD & 2.7 & 9.8 & 0.22 & 96.9 & 0.4 & 0.7 & 0.1 & $<\mathrm{LOD}$ & 4.4 \\
\hline KT-410 & $\begin{array}{l}\text { Qda. } \\
\text { Pantanos }\end{array}$ & $\begin{array}{l}\text { Dark grey } \\
\text { slurry }\end{array}$ & 1.5 & 57.3 & 200.8 & 26.12 & 218.6 & 18.8 & 30.2 & 37.4 & 142 & 671.1 \\
\hline KT-411 & $\begin{array}{l}\text { Qda. Los } \\
\text { Indios }\end{array}$ & Clear water & 4.5 & 16.9 & 26.7 & 2.41 & 140.8 & 8.4 & 1.8 & 0.5 & $<\mathrm{LOD}$ & 63.8 \\
\hline KT-412 & $\begin{array}{l}\text { Qda. } \\
\text { Chaurquia }\end{array}$ & $\begin{array}{l}\text { Relatively } \\
\text { clear }\end{array}$ & 0.3 & 9.1 & 25.0 & 1.95 & 118.0 & 8.1 & 0.7 & 0.1 & $<\mathrm{LOD}$ & 75.1 \\
\hline KT-413 & $\begin{array}{l}\text { Qda. San } \\
\text { Jorge }\end{array}$ & $\begin{array}{l}\text { Light } \\
\text { brown }\end{array}$ & 7.0 & 18.4 & 175.5 & 1.56 & 313.0 & 4.7 & 3.8 & 0.0 & $<\mathrm{LOD}$ & 691.1 \\
\hline KT-414 & $\begin{array}{c}\text { Canalon de } \\
\text { la Iglesia }\end{array}$ & $\begin{array}{l}\text { Dirty, } \\
\text { sediment }\end{array}$ & 261.1 & 280.1 & 1,974 & 317.11 & 3,521 & 1,307 & 5.3 & 41.9 & $<\mathrm{LOD}$ & 4,880 \\
\hline KT-415 & $\begin{array}{l}\text { Qda. } \\
\text { Cascabel }\end{array}$ & $\begin{array}{l}\text { Dark grey } \\
\text { slurry }\end{array}$ & 71.6 & 63.5 & 457.9 & 153.78 & 685.4 & 446.7 & 3.0 & 7.7 & 32 & 1,717 \\
\hline KT-416 & Rio Arquia & Brown & $<$ LOD & 2.6 & 27.0 & 0.31 & 160.9 & 1.0 & 0.8 & 0.1 & $<\mathrm{LOD}$ & 38.9 \\
\hline KT-417 & $\begin{array}{l}\text { Qda. Los } \\
\text { Indios }\end{array}$ & Clear & $<\mathrm{LOD}$ & 1.7 & 6.3 & 0.26 & 96.3 & 0.4 & 0.7 & 0.1 & $<\mathrm{LOD}$ & 6.1 \\
\hline KT-419 & Field Blank & Clear & $<\mathrm{LOD}$ & 0.6 & 4.3 & 0.14 & 0.4 & 0.3 & 0.0 & $<\mathrm{LOD}$ & $<\mathrm{LOD}$ & 0.6 \\
\hline KT-421 & $\begin{array}{l}\text { Qda. Aguas } \\
\text { Claras }\end{array}$ & Clear water & $<$ LOD & 2.2 & 5.3 & 0.24 & 481.2 & 0.4 & 1.4 & $<\mathrm{LOD}$ & $<\mathrm{LOD}$ & 7.2 \\
\hline $\begin{array}{l}\text { RSD of } \\
\text { analytes } \\
\text { better than } \\
10 \%\end{array}$ & & & & & & & & & & & & \\
\hline
\end{tabular}


Table 4 Elemental assay of selected metals from drill core samples $(n=22,009)$

\begin{tabular}{lllllllllllll}
\hline & $\begin{array}{l}\mathrm{Au} \\
\mathrm{ppm}\end{array}$ & $\begin{array}{l}\mathrm{Ag} \\
\mathrm{ppm}\end{array}$ & $\begin{array}{l}\mathrm{Cu} \\
\mathrm{ppm}\end{array}$ & $\begin{array}{l}\mathrm{Mo} \\
\mathrm{ppm}\end{array}$ & $\begin{array}{l}\mathrm{Pb} \\
\mathrm{ppm}\end{array}$ & $\mathrm{Zn} \mathrm{ppm}$ & $\begin{array}{l}\mathrm{As} \\
\mathrm{ppm}\end{array}$ & $\begin{array}{l}\mathrm{Sb} \\
\mathrm{ppm}\end{array}$ & $\begin{array}{l}\mathrm{Sn} \\
\mathrm{ppm}\end{array}$ & $\begin{array}{l}\mathrm{Hg} \\
\mathrm{ppm}\end{array}$ & $\begin{array}{l}\mathrm{Cd} \\
\mathrm{ppm}\end{array}$ & $\begin{array}{l}\mathrm{Cr} \\
\mathrm{ppm}\end{array}$ \\
\hline $\begin{array}{l}\text { Crustal } \\
\text { average }\end{array}$ & 0.0031 & 0.08 & 50 & 1.2 & 14 & 79 & 1.5 & 0.2 & 2.1 & 0.067 & 0.15 & 100 \\
Average & 0.31 & 2.37 & 54.40 & 2.22 & 115.98 & 909.44 & 64.85 & 4.36 & 4.08 & 0.684 & 15.83 & 162.74 \\
Max & 180 & 2,302 & 12,400 & 417 & 40,400 & 133,200 & 10,001 & 944 & 108 & 373 & 2,003 & 2,477 \\
Min & 0.003 & 0 & 0.25 & 0.025 & 0.25 & 0 & 0.5 & 0 & 0 & 0 & 0.01 & 0.5 \\
Std. Dev & 2.48 & 28.24 & 168.45 & 6.15 & 569.06 & 2814.78 & 278.09 & 10.10 & 2.89 & 5.331 & 49.18 & 128.65 \\
Median & 0.032 & 0.9 & 23 & 1 & 23 & 259 & 18 & 2.5 & 5 & 0.5 & 3.33 & 147 \\
Enrichment & 100.0 & 29.6 & 1.1 & 1.9 & 8.3 & 11.5 & 43.2 & 21.8 & 1.9 & 10.2 & 105.5 & 1.6 \\
\hline
\end{tabular}

Average crustal values are shown in parenthesis (Barbalace, 2020) for comparison

Analyses were performed by Barringer Laboratories Inc, SGS del Peru S.A.C and Inspectorate America Corporation in support of the exploration program, from 1996 to 2008

\section{References}

Alonso, D. L., Latorre, S., Castillo, E., \& Brandão, P. F. B. (2014). Environmental occurrence of arsenic in Colombia: A review. Environmental Pollution, 186, 272-281. https:// doi.org/10.1016/j.envpol.2013.12.009.

Barbalace, K. (2020). Periodic table of elements. https:// environmentalchemistry.com/yogi/periodic/Am.html. Accessed 16 June 2020.

Bosse Jønsson, J., Charles, E., \& Kalvig, P. (2013). Toxic mercury versus appropriate technology: Artisanal gold miners' retort aversion. Resources Policy, 38(1), 60-67. https://doi.org/10.1016/j.resourpol.2012.09.001.

Brooks, W. E. (2012). Colombia mercury inventory 2011. Geologia Colombiana, 37(2), 15-50.

Brooks, W. E., Restrepo, M. B., \& Cadena, A. M. (2016). Three gold-bearing prehispanic ceramic fragments from the Supia-Marmato Mining District, Rio Medio Cauca, Colombia. Archaeological Discovery, 4, 11-21.

Bundschuh, J., Litter, M. I., Parvez, F., Román-Ross, G., Nicolli, H. B., Jean, J.-S., et al. (2012). One century of arsenic exposure in Latin America: A review of history and occurrence from 14 countries. Science of The Total Environment, 429, 2-35. https://doi.org/10.1016/j.scitotenv. 2011.06.024.

Candeias, C., Ávila, P., Coelho, P., \& Teixeira, J. P. (2019).

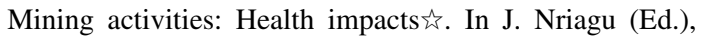
Encyclopedia of Environmental Health. (2nd ed., pp. 415-435). Elsevier.

Clifford, M. J. (2014). Future strategies for tackling mercury pollution in the artisanal gold mining sector: Making the Minamata convention work. Futures, 62, 106-112. https:// doi.org/10.1016/j.futures.2014.05.001.

Cordy, P., Veiga, M., Salih, I., Al-Saadi, S., Console, S., Garcia, O., et al. (2011). Mercury contamination from artisanal gold mining in Antioquia, Colombia: The Worlds's highest per capita mercury pollution. Science of the Total Environment., 410, 154-160.
Cullen, W. R., \& Reimer, K. J. (1989). Arsenic speciation in the environment. Chemical Reviews, 89(4), 713-764. https:// doi.org/10.1021/cr00094a002.

Ficklin, W. H. (1983). Separation of arsenic(III) and $\operatorname{arsenic}(\mathrm{V})$ in ground waters by ion-exchange. Talanta, 30(5), 371-373. https://doi.org/10.1016/00399140(83)80084-8.

García, O., Veiga, M. M., Cordy, P., Suescún, O. E., Molina, J. M., \& Roeser, M. (2015). Artisanal gold mining in Antioquia, Colombia: A successful case of mercury reduction. Journal of Cleaner Production, 90, 244-252. https://doi.org/10.1016/j.jclepro.2014.11.032.

Gibb, H., \& O'Leary, K. G. (2014). Mercury exposure and health impacts among individuals in the artisanal and small-scale gold mining community: A comprehensive review. Environmental Health Perspectives, 122(7), 667-672. https://doi.org/10.1289/ehp.1307864.

Gutierrez-Mosquera, H., Sujitha, S. B., Jonathan, M. P., Sarkar, S. K., Medina-Mosquera, F., Ayala-Mosquera, H., et al. (2018). Mercury levels in human population from a mining district in Western Colombia. Journal of Environmental Sciences (China), 68, 83-90. https://doi.org/10.1016/j.jes. 2017.12.007.

Haque, S., \& Johannesson, K. H. (2006). Arsenic concentrations and speciation along a groundwater flow path: The Carrizo sand aquifer, Texas, USA. Chemical Geology, 228, 57-71.

Hentschel, T., Hruschka, F., \& Priester, F. (2002). Global report on artisanal and small-scale mining. Working paper 70. Mining, minerals and sustainable development (MMSD) project. International Institute for Environment and Development (IIED), London.

Hilson, G., \& Pardie, S. (2006). Mercury: An agent of poverty in Ghana's small-scale gold-mining sector? Resources Policy, 31(2), 106-116. https://doi.org/10.1016/j.resourpol. 2006.09.001.

Holley, E. A., Smith, N. M., Delgado Jimenez, J. A., Cabezas, I. C., \& Restrepo-Baena, O. J. (2020). Socio-technical context of the interactions between large-scale and small-scale 
mining in Marmato, Colombia. Resources Policy, 67, 101696. https://doi.org/10.1016/j.resourpol.2020.101696.

Issa, N. B., Rajaković-Ognjanović, V. N., Jovanović, B. M., \& Rajaković, L. V. (2010). Determination of inorganic arsenic species in natural waters-benefits of separation and preconcentration on ion exchange and hybrid resins. Analytica Chimica Acta, 673(2), 185-193. https://doi.org/ 10.1016/j.aca.2010.05.027.

JBR Environmental Consultants Inc. (2011). Gran Colombia gold - Marmato project. . Knight Piésold and Co.

Knight Piésold Consulting. (2012). Marmato Mine. . Knight Piésold Consulting.

Marrugo-Negrete, J., Pinedo-Hernández, J., \& Díez, S. (2017). Assessment of heavy metal pollution, spatial distribution and origin in agricultural soils along the Sinú River Basin, Colombia. Environmental Research, 154, 380-388. https:// doi.org/10.1016/j.envres.2017.01.021.

Miller, G. (2000). A comment on arsenic species separation using ion exchange. Water Research, 34(4), 1397-1400. https://doi.org/10.1016/s0043-1354(99)00257-2.

Munk, L., Hagedorn, B., \& Sjostrom, D. (2011). Seasonal fluctuations and mobility of arsenic in groundwater resources. . Applied Geochemistry. https://doi.org/10. 1016/j.apgeochem.2011.06.005.

Palacios-Torres, Y., Caballero-Gallardo, K., \& Olivero-Verbel, J. (2018). Mercury pollution by gold mining in a global biodiversity hotspot, the Choco biogeographic region, Colombia. Chemosphere, 193, 421-430. https://doi.org/10. 1016/j.chemosphere.2017.10.160.

Parsons, B., \& Armitage, M. (2012). A NI 43-101 Mineral resource estimate on the Marmato project, Colombia, 4 September, 2011. SRK Consulting (UK) Ltd.

Parsons, B., Farias, C. P., Bird, D., Hoekstra, D., Olin, E. J., Rodrigues, F., et al. (2019). NI 43-101 technical report preliminary economic assessment. . SRK consulting (US) Inc.

Parsons, B., Olin, E., Rodrigues, F., Osborn, J., Poeck, J., Henriquez, F., et al. (2020). NI 43-101 technical report, pre-feasibility study, Marmato project. . SRK Consulting (US) Inc.

Peel, M. C., Finlayson, B. L., \& Mcmahon, T. A. (2007). Updated world map of the Köppen-Geiger climate classification. Hydrology and Earth System Sciences Discussions, 4(2), 439-473.

Prieto, G. (1998). Geochemistry of heavy metals derived from gold-bearing sulphide minerals in the Marmato District (Colombia). Journal of Geochemical Exploration, 64(1), 215-222. https://doi.org/10.1016/S0375-6742(98)00034$\mathrm{X}$.

Prieto, G. R., \& Gonzalez, M. L. (1998). Diagnosis of environmental problems related to vein gold mining in Colombia. In J. C. Wasserman, E. V. Silva-Filho, \& R. Villas-Boas (Eds.), Environmental geochemistry in the tropics. (pp. 185-191). Springer, Berlin Heidelberg.

Redwood, S. D. (2011) The Marmato gold deposit, Caldas, Colombia: A major porphyry-hosted, intermediate sulfidation epithermal deposit. In Simposia 10. Exploration de minerales, contribuciones a los depositas minerales y metalogenesis., 2011.

Santacruz, L., Redwood, S., Molano, J. C., \& Cecchi, A. (2014) Affinity between bismuth and gold in the Marmato gold deposit, Colombia: A probable case of the liquid bismuth collector model. In Society of economic geologists 2014 conference, Keystone, Colorado, USA, 27 - 30 Sept 2014.

Santacruz, R. L., Redwood, S., Matteini, M., Botelho, N., Cecchi, A., Ceballos, J., et al. (2018) Mesothermal to epithermal mineralization vein system at the Marmato gold deposit, Colombia. In 5th Quadrennial IAGOD International association on the genesis of ore deposits symposium, Salta, Argentina.

Leonardo Santacruz, R., Redwood, S. D., Cecchi, A., Matteini, M., Botelho, N. F., Ceballos, J., et al. (2020). The age and petrogenesis of reduced to weakly oxidized porphyry intrusions at the Marmato gold deposit, Colombia. Ore Geology Reviews. https://doi.org/10.1016/j.oregeorev. 2020.103953.

Selin, N. E. (2009). Global biogeochemical cycling of mercury: A review. Annual Review of Environment and Resources, 34(1), 43-63. https://doi.org/10.1146/annurev.environ. 051308.084314.

Telmer, K., \& Veiga, M. (2009). Chapter 6. World emissions of mercury from artisanal mining and small-scale gold mining. In N. Pirrone \& R. Mason (Eds.), Mercury fate and transport in the global atmosphere. (pp. 131-172). New York: Springer.

Torrance, K. (2012). Patterns of arsenic speciation and associated potentially toxic elements at sites impacted by mining and mine waste., University of Strathclyde, Glasgow, Scotland.

Torrance, K., Keenan, H., Munk, L., \& Hagedorn, B. (2012a). Arsenic speciation and mobility in surface water at Lucky Shot Gold Mine Alaska. Environmental Geochemistry and Health, 34(6), 711-723. https://doi.org/10.1007/s10653012-9490-y.

Torrance, K., Keenan, H. E., Munk, L., Hagedorn, B., Chen, B., \& Corns, W. T. (2012b). Arsenic speciation in surface water polluted from cinnabar ore processing at Red Devil, Alaska. 4th International Congress on Arsenic in the Environment,

UN Environmental Programme (2020). Minimata convention on mercury. http://www.mercuryconvention.org/Home/ tabid/3360/language/en-US/Default.aspx. Accessed June 162020.

Veiga, M. M., Angeloci, G., Hitch, M., \& Colon VelasquezLopez, P. (2014). Processing centres in artisanal gold mining. Journal of Cleaner Production, 64, 535-544. https://doi.org/10.1016/j.jclepro.2013.08.015.

Veiga, M. M., \& Marshall, B. G. (2019). The Colombian artisanal mining sector: Formalization is a heavy burden. The Extractive Industries and Society, 6(1), 223-228. https:// doi.org/10.1016/j.exis.2018.11.001.

WHO (2011). Guidelines for drinking-water quality. Fourth edition. World Health Organization.

Wilkie, J. A., \& Hering, J. G. (1998). Rapid oxidation of geothermal arsenic(III) in streamwaters of the Eastern Sierra Nevada. Environmental Science and Technology, 32(5), 657-662.

Publisher's Note Springer Nature remains neutral with regard to jurisdictional claims in published maps and institutional affiliations. 